\title{
NOTE ON THE GENUS FELICHTHYS OF SWAINSON.
}

\author{
BY \\ Theodore Gill, M. D, Ph. D.
}

The name Felichthys of Swainson has been ignored by common consent until recently. It has been lately restricted by Dr. and Mrs. Eigenmann to the auchenipterine genus called Pseudauchenipterus by Bleeker. This is, however, inadmissible, and if it must be used at all it is clearly to the one generally called Alurichthys it must be referred.

In 1838, Swainson, in "The Natural History and Classification of Fishes," etc. (vol. 1, p. 343), proposed the genus Breviceps for the Silurus bagre of Bloch and for that alone. "In this," he claimed, "the caudal fin is also lunate [as in Synodontis]; but the points are not extended like those of the first dorsal and pectoral rays, which reach to a very considerable length; the head is particularly short and obtuse, with the eyes very remote; and there are only two pairs of cirri, one of which is very short. The upper jaw is slightly longer than the under; it is very large, and armed with numerous sharp teeth, very small, placed in two broad rows in the upper jaw, and in one on the under; finally, the tougue is very large, thick, and rounded."

This definition (except as to the dentition*) is essentially applicable to the Silurus bagre although not truly diagnostic.

In 1839, Swainson, in the second volume of the same work (vol. 2, p. 189), still used the name Breviceps for the same geuus, but in the later "general arrangement" (vol. 2, p. 305) there was substituted for Brev. iceps, "a name already used in Erpetology," a new name, Felichthys. The genus was redefined as having the "head short, very obtuse, depressed, anal fin lengthened; vent central; caudal forked," and two species were referred to it, (1) " $F$. filamentosus, $\dagger$ Bl. pl. 365," and (2) "F. nodosus, Bl. 368, f. I."

No attention was subsequently paid to the genus. The hybrid nature of the name would be regarded by some as objectionable, and the per. fect ignorance of the composer has caused many to ignore the man completely. Perfectly as I agree with those who execrate the character of his work, I must, nevertheless, agree with those others who consider that the work itself, having been duly published, must receive due attention.

* The anterior of the two rows is intermaxillary; the pusterior vomero-palatine.

$\dagger$ A Felichthys filamentosus is described as a new species in Appendix (p. 392). It is F. marinus.

Proc. N. MI. 80 Proceedings National Museum, Vol. XIII.-No. 832. 23 
In 1862, Dr. von Bleeker retainer the name Pimelodus as the designation for the genus generally called Elurichthys, and would have re. ferred Felichthys to it as a synonym.

In 1882, Professor Swain (Proc. Acarl. Nat. Sc., Phila., p. 281) pro. posed to use Felichthys as the name for the genus called in 1840 by Cuvier and Valenciennes Auchenipterus.

In 1888 and later, Dr. and Mrs. Eigenmann, in their excellent memoirs on the South American Nematognaths, ${ }^{*}$ accepted Swainson's name Felichthys for the genus first defined by Bleeker, in 1862, uuder the name Pseudauchenipterus and typified by the Silurus nodosus of Bloch.

The fault with all the authors cited is that they have neglected to refer to the early portions of Swainson's work. If they had done so, they would have perceived that Swainson's name should be restored to the Silurus bagre, and, in that case, replace the generally accepted name Ailurichthys or Alurichthys. I presume there will be no difference of opinion as to the propriety of this course, and indeed Dr. and Mrs. Eigenmann would doubtless be the first to recognize the status. It is, therefore, desirable that the change should be made as speedily as possible.

The synonymy of the genus may be summarized as follows:

\section{FELICHTHYS.}

Synomymy.

Brcviceps Swainson, Nat. Hist. Fish., etc., v. 1, pp. 328, 343 (incl, Silurus bagre Bl.), 1838. (Not Brevi eps Merrem, 18:0.)

Felichthys Swainson, Nat. Hist. Fish, etc., v. 2, p. 305, 1839 (substitute for Breviceps, but with Silurus nodosus Bl. arlded).

Ailurichthys Baird and Girart, Proc. Acad. Nat. Sc., Phila., v. 7, p. 26, 1854.

AElurichthys Gill, Proc. Acad. Nat. Sc., Phila., 1863, p. 172, 1863. (Adopted by Günther, Steindachner, Cope, Jordan, Gilbert, Goode, Bean, et al.)

Pimelodus Bleeker, Atlas Ich. Iudes Neerland, v. 2, p. 8, 1862.

Four species of the genus are known, viz:

1. F. BAGRE= Silurus bagre Linn, 1766 .

2. F. MARINUS=Silurus marinus Mitehill, 1814.

3. F. PANAMENSIS=Elurichthys panamensis Gill, 1863.

4. F. Pinnimacleatus = Elurichthys pinnimaculatus Steind, 1876 .

SUMMARY.

(1) The genus Breviceps was based solely on the Silurus bagre and upon the examination of an actual specimen whose dorsal and pectoral fins were illustrated.

(2) The name Felichthys was formally "substituted for Breviceps, a name already used in Erpetology."

(3) Inasmuch as Felichthys was rigorously substituted for Breviceps, the same species was necessarily the type of each.

(4) The name Felichthys must take precedence of subsequently proposed names for the same type, e. g., ${ }^{\circ}$ Ailurichthy/s or Alurichthys.

*Proc. Cal. Acad. Sc. (2), vol. 1, p. 152, 1883; Occ. Papers Caì. Acad. Sc., vol. 1, p. 285,1890 . 


\section{$2 \mathrm{BHL}$ Biodiversity Heritage Library}

Gill, Theodore. 1891. "Note on the genus Felichthys of Swainson." Proceedings of the United States National Museum 13(832), 353-354.

https://doi.org/10.5479/si.00963801.13-832.353.

View This Item Online: $\underline{\text { https://www.biodiversitylibrary.org/item/53445 }}$

DOI: https://doi.org/10.5479/si.00963801.13-832.353

Permalink: https://www.biodiversitylibrary.org/partpdf/52059

\section{Holding Institution}

Smithsonian Libraries

\section{Sponsored by}

Smithsonian

\section{Copyright \& Reuse}

Copyright Status: Public domain. The BHL considers that this work is no longer under copyright protection.

This document was created from content at the Biodiversity Heritage Library, the world's largest open access digital library for biodiversity literature and archives. Visit BHL at https://www.biodiversitylibrary.org. 